\title{
Die gebruik van mitochondriale DNA-ondersoeke in geregtelik-geneeskundige wetenskappe
}

\author{
S. Dawson* en C. Weitz. \\ Forensiesewetenskaplaboratorium, Privaat sak X620, Pretoria, 0001
}

M.J. Pitout

Departement Fisiologie, Fakulteit Geneeskunde, Universiteit van Pretoria, Pretoria, 0001

Ontvang 13 Junie 1995; aanvaar 7 Maart 1996

\section{UITTREKSEL}

Verskeie metodes is ontwikkel om mitochondriale DNA (mtDNA) te karakteriseer. Die aanvanklike doel hiervan was om siektetoestande te probeer koppel aan spesifieke mitochondriale afwykings. Ander moontlike aanwendings van mitochondriale tegnieke, soos die ondersoek van die filogenetiese geskiedenis en bevolkingstrukture van die menslike bevolking het direk gevolg vanuit die moederlike oorerwingseienskap wat mtDNA toon. Mitochondriale tipering toon bowenal om uiters waardevol te wees as ' $n$ metode vir menslike identifikasie in geregtelik-geneeskundige ondersoeke. Die identifikasie van slagoffers van massarampe of -moorde is een van die uitdagendste velde in die geregtelik-geneeskundige wetenskappe. Deur gebruik te maak van geoutomatiseerde volgordebepaling met behulp van fluoresserende merkers, kan volgorde-inligting vinnig gegenereer word. Verklaring van hierdie volgordes vir geregtelik-geneeskundige doeleindes geskied deur middel van rekenaarsagteware wat volgordes vinnig met mekaar kan vergelyk, verskille tussen volgordes kan uitwys en individuele volgordes met 'n verwysingstandaard kan vergelyk.

\section{Abstract}

The use of mitochondrial DNA (mtDNA)-investigations in Forensic Sciences

$A$ variety of methods was developed to characterize mtDNA. The initial aim of these techniques was to try and link diseases with specific mitochondrial defects. As a result of the maternal inheritance trait of mtDNA these techniques facilitate studies of the phylogenetic history and population structure of the human population. It has been shown that mitochondrial DNA typing can be of great value for human identification in forensic cases. The identiflcation of victims of mass-disasters or mass-murders, where human remains can be recovered only after many years have passed, is one of the most challenging fields of forensic identification. By using automated DNA sequencing with fluorescent labels, mitochondrial DNA sequences can be generated rapidly and accurately. Computer software facilitates the rapid comparison of individual and reference sequences.

- Outeur aan wie korrespondensie gerig kan word 


\section{INLEIDING}

Menslike mitochondriale DNA (mtDNA) is 'n ekstrachromosomale, geslote sirkulêre, organel-spesifieke genoom wat uit ongeveer 16,5 kilobasisse (kb) bestaan. Die menslike mtDNA-volgorde is volledig bepaal. ${ }^{1}$ Dit bevat koderingsvolgordes vir twee ribosomale RNA's (rRNA), 22 oordrag. RNA's (tRNA), 13 proteiene en 'n niekoderende streek wat uit ongeveer 1100 basispare (bp) bestaan.

Die niekoderende streek staan ook bekend as die verplasingslus (D-lus) of kontrolestreek. Die meeste van die volgordevariasie tussen individue word in hierdie kontrolestreek gevind. ${ }^{2}$ Die dubbelketting $m t D N A$-molekuul bestaan uit een purienryke ketting en een pirimidienryke ketting wat onderskeidelik as die swaar ketting en die ligte ketting bekend staan. Nukleotied (nt) posisies in die mtDNA genoom word genommer volgens die konvensie van Anderson et al. (1981). ${ }^{1}$ Die numeriese toekenning van basispare begin by die oorsprong van replikasie van die swaar ketting, en strek om die genoom vir ongeveer 16569 bp.

Die afgelope aantal jare is verskeie metodes ontwikkel om mtDNA te karakteriseer. 3, 4, 3, 6, 7, 8. 9 Die doel hiervan was om siektetoestande te probeer koppel aan spesifieke mitochondriale afwykings. ${ }^{10,11,12,13}$ As gevolg van die moederlike oorerwing, kan die filogenetiese geskiedenis van die menslike bevolking nagespoor en bevolkingstrukturering ondersoek word. 79, 14, 15, 16. ${ }^{17}$ Die genetiese identifikasie wat betrokke is, kan egter ook toepassings in ander velde vind, byvoorbeeld die geregtelikgeneeskundige wetenskap waar positiewe identifikasie van menslike corskot en/of verdagte spore noodsaaklik is om die skuld of onskuld van die verdagte te bepaal. ${ }^{\circ}$

Die monoklonale geaardheid van mtDNA is ' $n$ belangrike eienskap in die vereenvoudiging van die volgordebepaling. ${ }^{18,19}$ Met die uitsondering van sekere siektetoestande waar weefselspesifieke weglatings van groot segmente van die mitochondriale genoom waargeneem is, is alle kopieë van 'n individu se mtDNA-volgorde vir praktiese doeleindes identies. ${ }^{20,21,22}$ Kern-DNA is egter diploïed en bestaan uit 'n moederlik-oorgeërfde stel chromosome en 'n vaderlikoorgeërfde stel chromosome. Om die volgorde van kern-DNA (met die uitsondering van die monoklonale Y-chromosoom) te bepaal, moet hierdie die twee allele eers geskei word.

As gevolg van die unieke wyse van oorerwing ondergaan mtDNA egter nie rekombinasie nie. Die lae betroubaarheid van mtDNA-polimerase en die skynbare gebrek aan 'n mtDNA mutageniese herstelmeganisme het oënskynlik gelei tot ' $n$ hoër tempo van mutasie in die mitochondriale genoom. Dit gee direk aanleiding tot 'n baie hoë mate van polimorfisme tussen individue binne hierdie streek. Sommige streke van die mtDNA-genoom skyn te ontwikkel teen 5 tot 10 keer die snelheid van enkelkopie-kerngene. ${ }^{17.23}$ Hierdie areas van relatiewe hoë muteerbaarheid het nogtans steeds goed behoue gebly. Dit is hierdie streke wat van geregtelik-geneeskundige belang is, omdat dit die geleentheid vir die geregtelikgeneeskundige wetenskaplike bied om tussen individue van die menslike bevolking te differensieer. Dit word geskat dat tussen Kaukasiërs daar vir elke 100 basisse, gemiddeld 1 nukleotied-verskil $(1 \%)$ in die mees varieerbare streke van mtDNA voorkom. ${ }^{17}$ Hierdie gemiddeld van ongeveer $2,3 \%$ is hoèr in individue wat van Negroïede afkoms is. ${ }^{16}$

In die geregtelik-geneeskundige wetenskap is die belangrikste voordeel wat tipering van mtDNA bo dié van kern DNA bied, die hoë kopiegetal. Terwyl elke stel kernchromosome teenwoordig is in slegs twee kopieè per sel, is mtDNA teenwoordig in honderde of selfs duisende kopieè per sel. In gevalle waar die hoeveelheid geëkstraeerde DNA baie min is, of gedegradeer is, byvoorbeeld in weefsel soos been, tande en hare, is die waarskynlikheid om 'n tiperingsresultaat met behulp van mtDNA te verkry, aansienlik beter as met polimorfiese merkers wat vanuit kernDNA verkry kan word.

' $n$ Verdere voordeel wat die ondersoek van $m t D N A$ bied in toevoeging tot sy hoër kopiegetal en gevolglike toename in sensitiwiteit, is die feit dat dit moederlik oorgeèrf word. ${ }^{24,25, ~} 26$ Uitgesonderd mutasies is die mtDNA-volgorde identies vir broers of susters en al hulle bloedverwante. Hierdie eienskap is nuttig in geregtelik-geneeskundige ondersoeke waar bekende bloedverwante aan moederskant verwysingsmonsters kan verskaf vir direkte vergelyking met die bevraagtekende mtDNA-tipe., 8. 28.29

Die identifikasie van slagoffers van massarampe of -moorde waarvan die oorblyfsels soms eers na baie jare gevind word, is een van die mees uitdagende velde van die geregtelikgeneeskundige wetenskappe. MtDNA-analises kan afgesien hiervan selfs ook gebruik word in gevalle waar etlike generasies die slagoffers en sy lewende afstammelinge skei. 'n Onlangse voorbeeld van hierdie tipe aanwending van mtDNA-tipering is die identifikasie van die oorbly fsels van die Russiese Romanov-familie. ${ }^{29}$ Nege skelette is in Julie 1991 in 'n vlak graf in Ekaterinburg, Rusland, gevind. Hierdie skelette is geïdentifiseer as die oorblyfsels van Tsaar Nicholas II, Tsarina Alexandra, drie van hulle vyf kinders, die huisdokter en drie bediendes. Die mtDNA-volgordes van die Tsarina en die drie kinders het presies met 'n moederlike bloedverwant ooreengestem. Die mtDNA-volgorde van die Tsaar het ooreengestem met twee moederlike bloedverwante. Heteroplasmie het by ' $n$ enkele basis in die mtDNAkontrolestreek voorgekom.

'n Verdere interessante aspek van mtDNA is die moontlikheid om die etniese agtergrond van 'n DNA-skenker te voorspel deur sy/haar mtDNA-volgorde te bepaal. ${ }^{30} \mathrm{Dit}$ blyk dat baie spesifieke mtDNA-volgordes in sommige etniese groepe gevind word. Gepaste gedefinieerde statistiese ramings en 'n uitgebreide databasis moet egter altyd sulke skattings van etnisiteit vergesel.

Die voordele verbonde aan die gebruik van mtDNA as substraat vir direkte volgordebepaling binne die geregtelik-geneeskundige veld kan as volg opgesom word:

\section{* Moederlike oorerwing}

Mitochondria word moederlik oorgeèrrf ${ }^{2 s}$ en is dus monoklonaal van aard, wat die potensièle probleem in die interpretasie van oorvleulende heterosigotiese volgordelere uitskakel.

\section{* Individualisering}

Interspesifieke oligohibridisasies ${ }^{27}$ en volgordestudies ${ }^{32}$ het aangetoon dat die meeste mtDNA-variasie binne die niekoderende streek voorkom.

Die niekoderende streek bevat die oorsprong van replikasie vir een ketting, beide oorspronge van transkripsie en die $D$ lus gebied. ${ }^{1}$ Hierdie volgordevariasie is veral gekonsentreer in twee segmente van ongeveer 400 basispare elk wat binne die D-lus gebied val en om die oorsprong van replikasie. ${ }^{2.14}$. 17. 33. 34 Elke segment kan individueel geanaliseer word en in 'n enkele volgordebepalingsreaksie gedoen word.

MtDNA toon aansienlike volgordevariasie tussen individue $^{17,35}$ omdat mtDNA vyf tot tien keer vinniger as kem- 
DNA ontwikkel. ${ }^{17}$ Hierdie hipervarieerbaarheid binne die niekoderende streek is reeds gebruik vir menslike identifikasiedoeleindes. ${ }^{6,31,34}$ 'n Gedeelte van die D-lusstreek van menslike mtDNA kan vermeerder en die volgorde kan bepaal word, sonder dat dit nodig is om klonering uit te voer.9. 36 Individualiteit kan geredelik bepaal word deur van die polimerase-kettingreaksie (PCR) gebruik te maak. Sodoende word vermeerdering van templaat-DNA bewerkstellig vir direkte geoutomatiseerde volgordebepaling. ${ }^{3,}{ }^{15}$ Alternatiewelik, kan die vermeerderde DNA gekenmerk word deur hibridisasie met volgordespesifieke oligonukleotied-peilers. ${ }^{7}$

\section{* Sensitiwiteit}

Die tegniek is baie sensitief met tussen 1000 en 10000 kopieè van die mitochondriale genoom teenwoordig in elke sel. ${ }^{37}$ Hierdie hoê kopiegetal tesame met die gebruik van die PCRproses van DNA-vermeerdering maak die gebruik van mtDNA soveel te meer geskik vir geregtelik-geneeskundige toepassings waar die materiaal gewoonlik uiters min en van swak gehalte is.

'n Enkele haar is genoegsaam vir identifikasiedoeleindes. ${ }^{31}$ Vermeerderingsprodukte kan verkry word van sowel die wortel- as skaggedeelte.

Deur gebruik te maak van PCR om minimale hoeveelhede DNA van oeroorblyfsels te vermeerder, is inligting verkry aangaande uitgestorwe spesies en bevolkings wat verdwyn het. ${ }^{38}$ ' $n$ MtDNA-volgorde is verkry vanaf 400 jaar oue menslike gemummifiseerde lewerweefse ${ }^{38}$ en vanaf 750 jaar oue bene. ${ }^{39}$ Vermeerdering vanaf oeroorblyfsels was meer suksesvol met mtDNA as met kern-DNA, moontlik as gevolg van die hoër kopiegetal van eersgenoemde. ${ }^{37}$

\section{Nadele verbonde aan die gebruik van mtDNA}

'n Potensiële nadeel van mtDNA-volgordebepaling is die arbeidsintensiewe aard van die tegniek; vir roetine geregtelikgeneeskundige analise moet die proses hoogs geoutomatiseer word om die volgorde-omset te maksimaliseer en die foute in datahantering te minimiseer en terselfdertyd databasishantering te vergemaklik. ${ }^{5}$ Hierdie is nou bereik deur onlangse vooruitgang in PCR-strategieë gekoppel met fluoressensiegebaseerde geoutomatiseerde volgordebepalingstegnologie.4' $n$ Verdere nadeel is die van kontaminasie, wat ' $n$ inherente gevaar van die PCR-proses van DNA-vermeerdering is. Daar moet dus altyd gepaste voorsorgmaatreèls getref word om kontaminasie te voorkom.

\section{DNA-volgordebepaling}

Mitochondriale DNA-tipering deur gebruik te maak van 'n verskeidenheid van metodes het getoon waardevol te wees as 'n metode van menslike identifikasie in baie geregtelikgeneeskundige ondersoeke. ${ }^{3,4,7.31}$ In sommige van hierdie gevalle is mtDNA-spesifieke oligonukleotied-hibridisasieondersoeke gebruik; ${ }^{7}$ in ander die handvolgordebepaling. ${ }^{3 .}$, ${ }^{28 .}{ }^{31} \mathrm{en}$ in ' $\mathrm{n}$ derde groep is fluoressensiegebaseerde geoutomatiseerde volgordebepaling van mtDNA gedoen. 40 Twee metodes vir volgordebepaling van DNA is in die laatsewentigerjare gepubliseer, ${ }^{40,41}$ waarvan die kettingterminasie, oftewel Sanger-metode, die algemeenste gebruik word.

Geoutomatiseerde volgordebepalers verskaf 'n hoë deurset en gemak van datahantering deur gebruik te maak van geskikte rekenaarsagteware. 'n Aantal verskillende volgordebepalingstrategieè is gebruik vir die volgordebepaling van PCR-gegenereerde template. ${ }^{42.43}$ Elke metode berus op die Sanger-dideoksi-termineringschemie.
Fluoressensie geoutomatiseerde DNA-volgordebepaling is in 1986 bekend gestel. ${ }^{44}$ In hierdie volgordebepalingsreaksies word fluoressiengemerkte oligonukleotiedvoorlopers of dideoksinukleotied-termineerders geînkorporeer in 'n DNA-fragment wat dan elektroforeties geskei en opgespoor word met behulp van lasergeïnduseerde fluoressensie. Sikliese volgordebepaling is 'n tegniek wat die dideoksi-termineringschemie met die sensitiwiteit van PCR kombineer. ${ }^{45}{ }^{46}$ Fluoressensiegebaseerde geoutomatiseerde volgordebepalers verloop vinnig en laat vinnige analise van volgorde-inligting toe as gevolg van geoutomatiseerde basistoekenning. Tesame met redigeringsagteware stel hierdie instrumente die gebruiker in staat om volgordes vinnig met mekaar te vergelyk, die verskille tussen verskeie volgordes te beklemtoon en individuele volgordes te vergelyk met ' $n$ verwysingstandaard. Om hierdie redes is hierdie benadering aantreklik vir die geregtelik-geneeskundige wetenskappe. ${ }^{4}$

\section{Dataformaat}

Die eerste volledige menslike mitochondriale volgorde is beskryf deur Anderson et al. (1981).' Hierdie volgorde word algemeen na verwys as die Anderson-volgorde, vernoem na die eerste outeur van die 1981-publikasie en word dikwels gebruik as die standaardvolgorde waarteen ander mensvolgordes vergelyk word. Die Anderson-volgorde word gelys as die ligtekettingvolgorde, teenoor die komplementêre swaarketting van die dubbelketting natuurlike DNA. Wanneer ' $n$ verskil tussen ' $n$ individu se volgorde en die Andersonvolgorde waargeneem word, word na die verskil verwys as 'n "polimorfisme-met-betrekking-tot-die-Andersonvolgorde".

Die oorgrote meerderheid polimorfismes word egter binne twee spesifieke segmente van die kontrolestreek gevind. ${ }^{2.47}$ Hierdie segmente word hipervarieerbare streek 1 (HV1) en hipervarieerbare streek 2 (HV2) genoem. Die grootte van elk van hierdie streke maak hulle vatbaar vir vermeerdering deur PCR, en is daarom bruikbaar vir geregtelik-geneeskundige doeleindes. Behalwe vir vervangings word invoegings en weglatings ook waargeneem as polimorfismes in menslike mtDNA. As gevolg van die potensiaal vir enkele nukleotiedvervanging in mtDNA kan 'n enkele basis die verskil tussen die kompromittering of verontskuldiging van 'n persoon in 'n geregtelik-geneeskundige saak beteken.

\section{Bevolkingsfrekwensie-berekeninge}

Wanneer ' $n$ mtDNA-tipe bepaal is, kan ' $n$ bepaling van die frekwensie van hierdie tipe in die algemene bevolking in die hof aangebied word as hulp met die oorweging van die gewig van die getuienis. Algemene databasisse, wat die inherente genetiese verskille van die hoofrasse van die mens in ag neem, moet saamgestel word. Hierdie databasisse moet monsters insluit wat van die algemene bevolking versamel is en moet verdeel word in Kaukasiese, Negroïede, Asiatiese en Kleurling-rassegroepe.

Paargewyse vergelykings van ' $n 380 \mathrm{bp}$-volgorde in die D-lus van 14 onverwante Kaukasiese individue, verskil gemiddeld by 5,9 basisse, wat ooreenstem met 'n moontlikheid van 1 in $370 .^{3}$

\section{SSO-tipering, 'n alternatief tot volgordebepaling}

'n Kragtige tegniek vir die opsporing van molekulêre genetiese variasie in menslike bevolkings is die analise van DNA-volgordes wat vermeerder is met behulp van PCR, en dan gehibridiseer is met volgordespesifieke oligonukleotied 
(SSO)-peilers. ${ }^{48,49,50}$ 'n SSO- tiperingsisteem vir variasie in menslike mtDNA-kontrolestreekvolgordes is ontwerp ${ }^{7}$ wat kan dien as ' $n$ metode van sifting voor daar oorgegaan word na volgordebepaling.

\section{Slotopmerking}

Mitochondriale DNA-tipering deur die gebruik van 'n verskeidenheid van metodes is waardevol as 'n metode van mensidentifikasie in baie geregtelik-geneeskundige ondersoeke. ${ }^{3,4,7,3 t}$ Daar is gevind dat fluoressensiegebaseerde geoutomatiseerde volgordebepalers vinnig verloop, en saam met geskikte rekenaarsagteware kan data vinnig verwerk word.

\section{SuMMARY}

\section{Introduction}

Human mitochondrial DNA (mtDNA) is an extrachromosomal, closed circular, organelle-specific genome consisting of approximately $16,5 \mathrm{~kb}$. The double-stranded $\mathrm{mtDNA}$ molecule is comprised of a heavy chain and a light chain. Human mtDNA has been sequenced completely and nucleotide positions are numbered according to the convention of Anderson et al. (1981). It consists of coding sequences for 2 ribosomal RNAs, 22 transfer RNAs, 13 proteins, and a noncoding region, approximately 1100 base pairs long, called the displacement loop (D-loop) or control region. Most sequence variations between individuals are found within this D-loop.

It has been estimated that amongst Caucasians an average of 1 nucleotide difference exists in every 100 bases (1\%) in the most variable regions of mtDNA. This average is higher in individuals of African descent, being approximately 2,3\%.

An important feature of $\mathrm{mtDNA}$, which simplifies DNA sequencing, is its monoclonal nature. With the exception of certain disease conditions where tissue-specific deletions of large segments of the mitochondrial genome have been detected, for practical purposes all copies of an individual's mtDNA sequence are identical. MtDNA sequencing can thus be used in the forensic sciences for positive identification of human remains.

MtDNA analysis can be used effectively where victims and living descendants are separated by many generations. An example is the identification of the remains of the Romanov family.

An interesting aspect of mtDNA is the possibility to predict the ethnic background of a DNA donor by his or her mtDNA sequence. Appropriately defined statistical estimates should always accompany such assessment of ethnicity.

\section{Advantages of using mtDNA}

\section{* Maternal inheritance}

In humans, mtDNA is maternaly inherited. This characteristic is helpful in forensic cases where known maternal relatives can provide reference samples for direct comparison with the questioned mtDNA type.

\section{* Individualisation}

The greatest sequence variation is concentrated in two segments of approximately 400 base pairs (bp) each within the D-loop and around the origin of replication. Each segment can be analysed individualy in a single sequencing reaction, and can then be used for human identification purposes. MtDNA sequences have been detected from the root and shaft region of a single hair.

\section{* Sensitivity}

The main advantage of typing mtDNA above nuclear DNA is its high copy number. In cases where the amount of extracted DNA is very small or degraded, such as bone, teeth and hair, the probability of obtaining a DNA typing result from mtDNA is higher than that of polimorphic markers found in nuclear DNA.

\section{Disadvantages of using mtDNA}

A high level of automation would be required for the technique to be introduced into forensic analysis on a routine basis. This has been achieved by recent progress made in PCR strategies linked with fluorescent based automated sequence determining technology.

\section{DNA seyuencing}

Fluorescent automated DivA sequencing was introduced in 1986. Automated sequencers provide high throughput and ease of data management through accompanying computer software. A number of different sequencing strategies have been used for sequencing PCR-generated templates. Each method is based on the Sanger dideoxy terminator chemistry.

\section{Data formating}

The first entire mitochondrial sequence was described by Anderson et al. (1981), and it is often used as a standard sequence, to which other human sequences are compared.

\section{Population frequency calculations}

General databases, which take into consideration the hereditary genetic dissimilarities of the major human races, should be compiled.

\section{SSO typing, an alternative to sequencing}

A SSO-typing system has been designed to detect variation in human mtDNA control region sequences.

\section{Conclusion}

By using a variety of methods for mtDNA typing it was shown to be a valuable method for human identification in many forensic cases.

\section{DANKBETUIGING}

Ons wil graag vir Arnold Greyling bedank vir die bydrae wat hy gelewer het met die taalkundige versorging van die artikel.

\section{LITERATUURVERWYSINGS}

1. Anderson, S., Bankier, A.T., Barrell, B.G., de Bruijin, M.H.L., Coulson, A.R., Drouin, J., et al. (1981). Sequence and Organisation of the Human Mitochondrial Genome, Nature, 290(5806), 457-465.

2. Greenberg, B.D., Newbold, J.E. \& Sugino, A. (1983). Intraspecific Nucleotide Sequence Variability Surrounding the Origin of Replication in Human Mitochondrial DNA, Gene, 21, 33-49.

3. Orrego, C. \& King, M.C. (1990). In PCR Protocols: A Guide to Methods and Applications, Innis, M.A., Gelfand, D.H., Sninsky, J.J. \& White, T.J. eds. (Academic Press, London) p.416-426.

4. Hopgood, R., Sullivan, K.M. \& Gill, P. (1991). Strategies for Automated Sequencing of Human Mitochondrial DNA Directly from 
PCR Products, Biotechniques, 13, 82-92.

5. Sullivan, K.M., Hopgood, R., Lang. B, \& Gill, P. (1991). Automated Amplification and Sequencing of Human Mitochondrial DNA, Electrophoresis, 12, 17-21.

6. Sullivan, K.M., Hopgood, R. \& Gill, P. (1992). Identification of Human Remains by Amplification and Automated Sequencing of Mitochondrial DNA, Int. J. Legal Med., 105. 83-86.

7. Stoneking, M., Hedgecock, D., Higuchi, R.G., Vigilant, L. \& Erlich, HA. (1991). Population Variation of Human mtDNA Control Region Sequences Detected by Enzymatic Amplification and Sequence-Specific Oligonucleotide probes, Am. J. Hum. Genet., 48. 370-382.

8. Ginther, C., Issel-Traver, L. \& King, M.C. (1992). Identifying Individuals by Sequencing Mitochondrial DNA from Teeth, Nature Genetics, 2, 135-138.

9. Wrischnik, L.A., Higuchi, R.G., Stoneking, M., Erlich, H.A., Arnheim, N. \& Wilson, A.C. (1987). Length mutations in human mitochondrial DNA:direct sequencing of enzymatically amplified DNA, Nucl. Acids Res, 15, 529-542

10. Hess, J.F., Parisi, M.A., Bennet, J.L. \& Clayton, D.A. (1991). Impairment of mitochondrial transcription termination by a point mutation associated with the MELAS subgroup of mitochondrial encephalmoyopathies, Nature. 351, 236-239.

11 Mc Shane, M.A., Hammans, S.R., Sweeney, M., Holt, I.J., Beattie, T.J., Brett, E.M. et al. (1991). Pearson Syndrome and mitochondrial encephalomyopathy in a patient with a deletion of mtDNA, Am. J. Hum. Genet., 48, 39.42.

12. Lestienne, P. (1992). Mitochondrial DNA mutations in human diseases: a review, Biochimie, 74, 123-130.

13. Trischler, H.J., Andreetta, F., Moreas, C.T., Bonilla, E., Arnaudo, E., Danon, M.J. et al. (1992). Mitochondrial myopathy of childhood associated with depletion of mitochondrial DNA, Neurology, 42, 209-217.

14. Aquadro, C.F. \& Greenberg, B.D. (1983). Human Mitochondrial DNA Variation and Evolution: Analysis of Nucleotide Sequences from Seven Individuals, Genetics, 103, 287-312.

15. Vigilant, L., Pennington, R., Harpending, H. \& Kocher, T.D. (1989). Mitochondrial DNA Sequences in Single Hairs from a Southern African Population, Proc. Natl. Acad. Sci. USA, 86, 9350-9354.

16. Vigilant, L., Stoneking, M., Harpending, H., Hawkes, K. \& Wilson, A.C. (1991). African Populations and the Evolution of Human Mitochondrial DNA, Science, 253, 1503-1507.

17. Cann, R.L., Stoneking, M. \& Wilson, A.C. (1987). Mitochondrial DNA and Human Evolution, Nature, 325(6099), 457 465 .

18. Jakovcic, S., Casey, J. \& Rabinowitz, M. (1975). Sequence homology between mitochondrial DNAs of different eukaryotes, Biochemistry, 14, 2043-2050.

19. Potter, S.S., Newbold, J.J., Hutchinson, C.A. \& Edgell, M.H. (1975). Specific claevage analysis of mammalian mitochondrial DNA, Proc. Natl. Acad. Sci. USA, 72, 4496- 4500.

20. Monnat, R.J. \& Loeb, L.A. (1985). Nucleotide Sequence Preservation of Human Mitochondrial DNA, Proc. Natl. Acad. Sci. USA, 82, 2895-2899.

21. Monnat, R.J., Maxwell, C.L. \& Loeb, L.A. (1985). Nucleotide Sequence Preservation of Human Leukemic Mitochondrial DNA, Cancer Res., 45, 1809-1814.

22. Monnat, R.J. \& Reay, D.T. (1986). Nucleotide Sequence Identity of Mitochondrial DNA from Different Human Tissues, Gene, 43, 205-211

23. Brown, W.M., Prager, E.M., Wang, A. \& Wilson, A.C. (1982). Mitochondrial DNA Sequences of Primates: Tempo and Mode of Evolution, J. Mol. Evol., 18, 225-239

24. Case, J.T. \& Wallace, D.C. 1981), Maternal Inheritance of Mitochondrial DNA Polymorphisms in Cultured Human Fibroblasts, Somatic Cell Genetics, 7, 103-108.

25. Giles, R.E., Blanc, H., Cann, H.M. \& Wallace, D.C. (1980). Maternal Inheritance of Human Mitochondrial DNA, Proc. Natl. Acad. Sci.USA, 77(11), 6715-6719.

26. Hutchinson, C.A., Newbold, J.E., Potter, S.S. \& Edgell, M.H. (1974). Maternal Inheritance of Mammalian Mitochondrial DNA, Nature. 251, 536-538

27. Upholt, W.B. \& Dawid, I.B. (1977). Mapping of mtDNA of individual sheep and goats: rapid evolution in the D-loop region, Cell, 11, 571-583.

28. Holland, M.M., Fisher, D.L., Mitchell, L.G., Rodriguez, W.C., Canik, J.J., Merril, C.R. et al. (1993). Mitochondrial DNA Sequence Analysis of Human Skeletal Remains: Identification of Remains from the Vietnam War, J. Forens. Sci., 38, 542- 553.

29. Gill, P., Ivanov, P.L., Kimpton, C., Piercy, R., Benson, N., Tully, G. et al. (1994). Identification of the remains of the Romanov family by DNA analysis, Nature Genetics, 6, 130-135.

30. Horai, S., Kondo, R., Nakagawa-Hattori, Y., Hayashi, S., Sonoda, S. \& Tajima, K. (1993). Peopling of the Americas, Founded by Four Lineages of Mitochondrial DNA, Mol. Biol. Evol., 10, 23-47.

31. Higuchi, R., von Beroldingen, C.H., Sensabaugh, G.F. \& Erlich, H.A. (1988). DNA Typing from Single Hairs, Nature, 332, 543546.

32. Walberg, M.W. \& Clayton, D.A. (1981). Sequence and properties of the human $\mathrm{KB}$ cell and mouse $\mathrm{L}$ cell $\mathrm{D}$-loop regions of mitochondrial DNA, Nucl. Acids Res., 9, 5411-5421.

33. Horai, S. \& Hayasaki, K. (1990). Intraspecific Nucleotide Sequence Differences in the Major Noncoding Region of Human Mitochondrial DNA, Am. J. Hum. Gen., 46, 828-842.

34. Kochner, T.D. \& Wilson, A.C. (1991). In Evolution of life, Osawa, S. \& Honja, T. eds. (Springer, Tokyo) p.391-413.

35. Aquadro, C.F. \& Greenberg, B.D. (1983). Human Mitochondrial DNA Variation and Evolution: Analysis of Nucleotide Sequences from Seven Individuals, Genetics, 103, 287-312.

36. Wong, C., Dowling, C.E., Saiki, R.K., Higuchi, R.G., Erlich, H.A. \& Kazazian, H.H. (1987). Characterization of _- thalassaemia mutations using direct genomic sequencing of amplified single copy DNA, Nature, 330, 384-386.

37. Bogenhagen, D. \& Clayton, D.A. (1974). The Number of Mitochondrial Deoxyribonucleic Acid Genomes in Mouse $\mathrm{L}$ and $\mathrm{Hu}$ man HeLa Cells, J. Biol. Chem., 249, 7991-7995.

38. Pääbo, S., Higuch, R.G. \& Wilson, A.C. (1989). Ancient DNA and the Polymerase chain reaction, J. Biol. Chem. 264, 9709- 9712.

39. Hagelberg, E., Sykes, B. \& Hedges, R. (1990). Ancient Bone DNA Amplified, Nature, 342, 485

47.Piercy, R., Sullivan, K.M., Benson, N. \& Gill P. (1993). The application of mitochondrial DNA typing to the study of White Caucasian genetic identification, Int. J. Legal Med., 106, 85-90.

42. Maxam, A.M. \& Gilbern, W. (1977). New method for sequencing DNA, Proc. Natl. Acad. Sci. USA, 74, 560-564.

43. Sanger, F., Nicklen, S. \& Coulsen, A.R. (1977). DNA sequencing with chain-terminating inhibitors, Proc. Natl. Acad. Sci. USA., 74, 5463-5468.

44. Ellingboe, J. \& Gyllensten, B. (1992). The PCR Technique: DNA Sequencing (Eaton, Natick, MA).

45. Gyllensten, U.B. \& Erlich, H.A. (1988). Generation of SingleStranded DNA by the Polymerase Chain Reaction and its Application to Direct Sequencing of the HLA-DQA Locus, Proc. Natl. Acad. Sci. USA, 85, 7652-7656.

46. Smith, L.M., Sanders, J.Z., Kaiser, R.J., Highes, P., Dodd, C., Connell, C.R. et al. (1986). Fluorescence detection in automated DNA sequence analysis, Nature, 321, 674-679.

47. Carothers, A.M., Urlaub, G., Mucha, J., Grunberger, D. \& Chasin, L.A. (1989). Point mutation analysis in a mammalian gene: Rapid preparation of total RNA, PCR amplification of CDNA, and Taq sequencing by a novel method, Biotechniques, 7, 494-499.

48. Murray, V. (1989). Improved double-stranded DNA sequencing using the linear polymerase chain reaction, Nucl. Acids Res., 17, 8889.

49. Saiki, R.K., Bugawan, T.L., Horn, G.T., Mullis, K.B. \& Erlich, H.A. (1986). Analysis of enzymatically amplified _- globin and HLADQ_DNA with allele-specific oligonucleotide probes, Nature, 324, 163-166.

50. Goedde, H.W., Singh, S., Agarwal, D.P., Fritze, G., Stapel, K. \& Paik, Y.K. (1989). Genotyping of Mitochondrial Aldehyde Dehydrogenase in Blood Samples using Allele-Specific Oligonucleotides: Comparison with Phenotyping in Hair Roots, Human Generics, 81, 305-307.

51. Helmuth, R., Fildes, N., Blake, E., Luce, M.C., Chimera, J., Madej, R., et al. (1990). HLA-DQ_Allele and Genotype Frequencies in Various Human Populations, Determined by Using Enzymatic Amplification and Oligonucleotide Probes, Am. J. Hum. Gen., 47, 515-523. 